\title{
Pemerolehan Bahasa Pertama pada Anak Usia Dini
}

\author{
Indah Permatasari Suardi ${ }^{1}$, Syahrul $\mathbf{R}^{2}$, Yasnur Asri ${ }^{3}$ \\ Pascasarjana Universitas Negeri Padang
}

\begin{abstract}
This study aims to describe the language acquisition of early childhood in the process of acquiring language through what is heard and practiced with the language and communication of the words they have. This study uses a qualitative descriptive research design because this study presents the results of research based on facts that exist in the speakers' daily lives and the process of acquiring language in the phonological aspects of children. The data obtained is the result of research through observation, diary notes, and interviews. The results of this

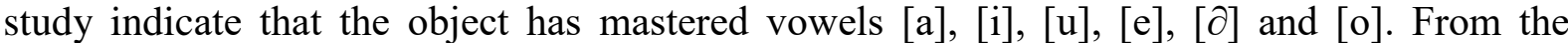
description above, it can be concluded that the acquisition of language in children in the phonological aspects is influenced by environmental factors, especially the hat family, which is characterized by the number of vocabulary vocabulary they get in the family environment and around.
\end{abstract}

Keywords: phonology, acquisition of children's language, vowels and consonants

\begin{abstract}
Abstrak
Penelitian ini bertujuan memaparkan pemerolehan bahasa anak usia dini dalan proses pemerolehan bahasa melalui apa yang di dengar dan di praktekkan dengan bahasa dan komsonan kata yang mereka miliki. Penelitian ini menggunakan rancangan penelitian deskriptif kualitatif karena penelitian ini memaparkan hasil penelitian berdasarkan fakta yang ada dalam kehidupan sehari hari penuturnya dan proses pemerolehan bahasa pada aspek fonologi anak. Data yang diperoleh adalah hasil penelitian melalui observasi, catatan harian, dan wawancara. Hasil penelitian ini menunjukkan objek sudah menguasai huruf-huruf vokal

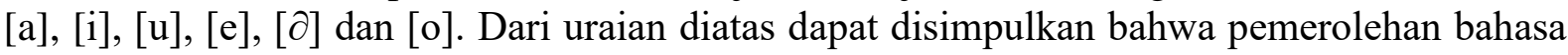
pada anak dalam aspek fonologi di pengaruhi faktor lingkungan khususnya keluarga hal tersebut ditandai dengan banyaknya pembendaharaan kosakata yang mereka dapatkan di lingkungan keluarga dan sekitar. Anak juga sudah bisa mengujarkan beberapa kata benda, kata kerja, dan kata sifat.
\end{abstract}

Kata Kunci: fonologi, pemerolehan bahasa anak, vokal dan konsonan

@ Jurnal Obsesi Prodi PG-PAUD FIP UPTT 2019

$\triangle$ Corresponding author :

Address : Padang, Sumatera Barat

Email : suardiindah@gmail.com

ISSN 2356-1327 (Media Cetak)

ISSN 2549-8959 (Media Online 


\section{PENDAHULUAN}

Bahasa merupakan alat komunikasi yang diperoleh manusia sejak lahir. Penguasaan sebuah bahasa oleh seorang anak dimulai dengan perolehan bahasa pertama yang sering kali disebut bahasa ibu. Bahasa pada hakikatnya merupkan sistem lambang bunyi yang arbitrer yang digunakan oleh anggota kelompok sosial untuk bekerja sama, berkomunikasi, dan mengidentifikasikan diri (Kridalaksana, 2002). Lebih lanjut, Owen (Solehan, 2011) menjelaskan bahwa bahasa dapat didefinisikan sebagai kode yang diterima secara sosial atau sistem konvensional untuk menyampaikan konsep melalui kegunaan simbol-simbol yang dikehendaki dan kombinasi simbol-simbol yang diatur oleh ketentuan).

Pemerolehan bahasa (language acquisition) atau akuisisi bahasa menurut Maksan (1993:20) adalah suatu proses penguasaan bahasa yang dilakukan oleh seseorang secara tidak sadar, implisit dan informal. Dardjowidjojo (Dardjowidjojo, 2003) menyatakan bahwa pemerolehan bahasa adalah proses penguasaan bahasa yang dilakukan oleh anak secara natural waktu dia belajar bahasa ibunya.

Seseorang tidak dengan tiba-tiba memiliki tata bahasa yang lengkap dengan semua kaidah dalam otaknya. Bahasa pertama diperoleh oleh seorang anak dalam beberapa tahap, dan setiap tahap berikutnya lebih mendekati tata bahasa dari bahasa orang dewasa. Istilah pemerolehan merupakan padanan kata acquisition. Istilah ini dipakai dalam proses penguasaan bahasa pertama sebagai salah satu perkembangan yang terjadi pada seorang manusia sejak lahir (Darmojuwono, 2005: 24). Secara alamiah anak akan mengenal bahasa sebagai cara berkomunikasi dengan orang di sekitarnya. Bahasa pertamayang dikenal dan selanjutnya dikuasai oleh seorang anak disebut bahasa ibu (native language) (Dardjowidjojo, 2003).

Pemerolehan bahasa pertama sangat berkaitan dengan perkembangan sosial anak dan pembentukan identitas sosial. Mempelajari bahasa pertama merupakan salah satu perkembangan menyeluruh anak menjadi anggota suatu masyarakat (Yogatama, 2011). Mengenai pemerolehan bahasa (language acquisition) atau akuisisi bahasa ini terdapat beberapa pengertian. Menurut Tarigan (Tarigan, 1988), pemerolehan bahasa merupakan proses pemilikan kemampuan berbahasa, baik berupa pemahaman atau pun pengungkapan secara alami, tanpa melalui kegiatan pembelajaran formal. Selanjutnya, Dardjowidjojo (Dardjowidjojo, 2003) menyatakan bahwa pemerolehan bahasa adalah proses penguasaan bahasa yang dilakukan oleh anak secara natural sewaktu anak belajar bahasa ibunya.

Menurut Manurung, pemerolehan bahasa pada anak mempunyai ciri-ciri berkesinambungan, merupakan suatu rangkaian kesatuan, dan dimulai dari ujaran satu kata yang sederhana hingga mencapai gabungan kata dan kalimat yang lebih rumit (Salnita, 2019). Pemerolehan bahasa biasanya dibedakan dengan pembelajaran bahasa. Pemerolehan bahasa biasanya terjadi secara alamiah, tanpa disadari, diperoleh dalam ruang lingkup kehidupan sehari-hari, sedangkan pada pembelajaran bahasa, bahasa diperoleh setalah dipelajari secara formal dengan mematuhi konsep-konsep kaidah ketatabahasaan yang berlaku (Chaer, 2003). Menurut Troike dalam pemerolehan bahasa kedua, semua fitur penting yang diasumsikan sebagai bahasa kedua diasumsikan sebagai bahasa pada anak usia dini. Biasanya pemerolehan bahasa kedua dimulai dari usia tiga dan mereka belajar bahasa dari orang sekitar 
yang berbicara kepada mereka (Troike, 2006).

Sejak usia dini, bayi telah berinteraksi di dalam lingkungan sosialnya. Seorang ibu seringkali memberi kesempatan kepada bayi untuk ikut dalam komunikasi sosial, maka pada saat itulah bayi pertama kali mengenal sosialisasi bahwa dunia ini adalah tempat orang saling berbagi rasa. Melalui bahasa pertama (B1), seorang anak belajar untuk menjadi anggota masyarakat. B1 menjadi salah satu sarana untuk mengungkapkan perasaan, keinginan, dan pendirian, dalam bentukbentuk bahasa yang dianggap ada. Anak belajar pula bahwa ada bentuk-bentuk yang tidak dapat diterima anggota masyarakatnya, anak tidak boleh selalu mengungkapkan perasaannya secara terusterang.

Pemerolehan bahasa pertama atau bahasa ibu anak-anak di seluruh dunia sama. Kesamaan proses pemerolehan tidak hanya disebabkan oleh persamaan unsur biologi dan neurologi bahasa, tetapi juga oleh adanya aspek mentalitas bahasa (Arifuddin, 2010). Jadi, dapat disimpulkan bahwa bahasa pertama (B1) atau bahasa ibu adalah bahasa yang pertama kali diperoleh oleh seorang individu dalam kehidupannya. Bahasa ini akan menjadi bahasa yang paling menurani dan sering digunakan oleh pemakai bahasa.

Penelitian mengenai bahasa pertama anak sudah banyak dilakukan di Indonesia. Dari penelitian yang dilakukan oleh Amelin (Amelin, 2019) dapat disimpulkan bahwa melalui ekspresi muka dan gerak tubuh yang diperlihatkan oleh seorang anak dapat membantu orang di sekitar untuk bisa memahami bahasa yang diucapkan oleh anak tersebut. Penelitian yang dilakukan oleh Salnita (Salnita, 2019) memperoleh hasil bahwa pada usia tiga tahun anak belum bisa mengujarkan fonem /r/ dan /s/ dengan benar. Kata-kata yang dikuasai oleh anak adalah kata-kata yang dekat dengan lingkungan anak dan semua ujaran anak pada usia ini mengandung makna denotatif. Penelitian yang dilakukan oleh Yumi (Yumi, 2019) memperoleh hasil bahwa pada usia empat tahun anak yang berada pada masa kontruksi sederhana sudah mampu mengujarkan kalimat dalam bentuk kalimat deklaratif, interogatif, dan imperatif.

Menurut Ingram dalam penelitian Palenkahu (Palenkahu, 2005) pemerolehan bahasa pertama dibagi menjadi empat periode. Pertama, tahap pendahuluan ditandai dengan tiga jenis tingkah laku yaitu membabel, meniru, dan pemahaman awal. Kedua, periode pertama (1-1,6 tahun) anak memeroleh sejumlah bunyi dengan makna khusus yang menyatakan ide suatu kalimat secara menyeluruh, akan tetapi tidak ada bukti anak memahami tata bahasa. Ketiga, periode kedua (1,6-2,0) anak menyadari bahwa segala sesuatu mempunyai makna sembutran yang beruntun dalam pemerolehan kata dan pertanyaan tentang nama benda. Keempat, periode $(2,0-2,6)$ anak mulai membentuk kalimat dengan baik dalam arti berisi katakata untuk relasi gramatikal utama subjek dan predikat.

Perkembangan pemerolehan bahasa anak dapat dibagi tiga bagian yaitu sebagai berikut. Pertama, perkembangan prasekolah. Tahap perkembangan pra sekolah terdiri atas tiga tahap perkembangan, yaitu perkembangan pralinguistik, tahap satu kata, dan ujaran kombinasi permulaan. Pada perkembangan pralinguistik anak, anak mengembangkan konsep dirinya. Ia berusaha membedakan dirinya dengan subjek, dirinya dengan orang lain, serta hubungan dengan objek dan tindakan. Pada tahap satu kata anak terus menerus berupaya mengumpulkan nama-nama benda dan orang yang dijumpai. Kedua, perkembangan ujaran 
kombinatori. Ketiga, perkembangan masa sekolah.

Penelitian ini diharapkan dapat bermanfaat secara teoritis dan praktis. Secara teoritis dapat bermanfaat untuk menambah ilmu pengetahuan mengenai pemerolehan bahasa pertama anak. Penelitian ini juga dapat bermanfaat bagi orang tua untuk bisa memahami apa yang diucapkan oleh anak mereka. Jika orang tua bisa memahami apa yang diucapkan oleh anak, maka anak akan menjadi senang. Komunikasi akan terjalin baik antara orang tua dan anak. Anak akan merasakan kedekatan batin dengan orangtua. Hal tersebut akan membantu psikologi anak tumbuh menjadi lebih baik.

\section{METODOLOGI}

Metode yang digunakan dalam penelitian ini adalah metode deskriptif dengan pendekatan kualitatif. Menurut Nazir (Nazir, 2011), metode deskriptif adalah metode yang meneliti suatu kelompok manusia, suatu subjek, atau pemikiran pada masa sekarang. Metode deskriptif ini digunakan untukmemberi gambaran hasil dari pengumpulan data yang telah dilakukan oleh peneliti, melalui wawancara (orang tua, anak) dan observasi secara langsung ke lapangan, tentang ujaran yang diucapkan oleh subjek penelitian. Metode deskriptif dipilih oleh peneliti karena metode ini dapat memberikan gambaran secermat mungkin mengenai individu, keadaan, bahasa, gejala, atau kelompok,

Penelitian ini dilakukan dengan cara mengamati secara langsung anak yang menjadi subjek penelitian. Karena seorang anak tidak secara tiba-tiba memiliki tata bahasa yang teratur dalam otaknya. Tahap pemerolehan bahasa pertama berkaitan dengan perkembangan bahasa anak. Hal ini dikarenakan bahasa pertama diperoleh seseorang pada saat ia berusia anak-anak. Peneliti ini menerapkan teknik simak libat cakap. Peneliti menyimak kata-kata yang bisa diucapkan oleh anak setelah itu Peneliti juga ikut berinteraksi dan mendorong subjek penelitian untuk mengucapkan kata-kata. Data dikumpulkan dengan cara mengamati dan memahami bahasa yang diujarkan oleh subjek penelitian. Peneliti akan merekan setiap kata dan ujaran yang dilontarkan oleh subjek penelitian. Penelitian ini dilakukan kurang lebih selama 3 minggu.

Tahap analisis data dalam penelitian ini terdiri atas tiga tahap, yaitu sebagai berikut. Pertama, reduksi. Reduksi dilakukan dengan empat cara, yaitu a) melakukan proses transkripsi data tuturan ke dalam bentuk tulisan; b) data yang telah ditranskripsikan kemudian diidentifikasi; c) melakukan proses pengklasifikasian; d) melakukan pemaknaan terhadap data yang sebelumnya sudah diklasifikasikan. Kedua, tahap penyajian. Pada tahap penyajian ini, data yang telah diklasifikasikan disajikan dalam bentuk tabel. Ketiga, tahap penarikan kesimpulan. Dalam tahap ketiga ini, dilakukan proses verifikasi ulang terhadap data awal yang sudah dikumpulkan (Miles dan Huberman, 2014).

\section{HASIL DAN PEMBAHASAN}

Kata-kata yang pertama diperolehnya pada tahap ini lazimnya adalah kata yang menyatakan perbuatan, sifat, dan kata benda. Perkembangan bahasa pertama anak lebih mudah ditandai dari kata yang mampu diucapkan. Jumlah kata yang diucapkan anak merupakan indikator atau petunjuk perkembangan bahasanya.

Di bawah ini adalah tabel hasil pengamatan pemerolehan bahasa pertama anak usia satu tahun dari aspek perkembangan morfologi bahasa Minang pada anak bernama Zayna Falisa Humaira. 


\begin{tabular}{|c|c|c|}
\hline \multirow[b]{2}{*}{ No } & \multicolumn{2}{|r|}{ morfem } \\
\hline & Kata & Arti \\
\hline 1 & ah & Ayah = Ayah \\
\hline 2 & bu-bu & $I b u=\mathrm{Ibu}$ \\
\hline 3 & mam & Makan = makan \\
\hline 4 & dak & Indak = tidak \\
\hline 5 & nnek & nenek $=$ nenek \\
\hline 6 & kek & Kakek $=$ kakek \\
\hline 7 & cik & Acik = paman \\
\hline 8 & ak & Apak = Paman \\
\hline 9 & num & Minum = Minum \\
\hline 10 & Pin pin & Upin-Ipin = Film \\
\hline 11 & aek & Mak gaek = Nenek \\
\hline 12 & tuk & datuk = kakek \\
\hline 13 & cak & Rancak = bagus \\
\hline 14 & mih & Mami = mami \\
\hline 15 & kut & Ikuik= Ikut \\
\hline
\end{tabular}

Berdasarkan hasil pencatatan terdapat $\geq 15$ kata yang dimiliki anak. Kata-kata yang diucapkan umumnya meniru ucapan ibunya yang kemudian dihubungkan dengan benda atau sifat. Dalam mengucapkan kata, anak lebih sering mengucapkan suku kata belakang misalnya mik (mimik=minum), em $($ maem=makan), bok (ceblok=jatuh), nuk (manuk=burung) dan sebagainya.

Kata-kata yang diucapkan dan dikuasai anak adalah kata benda, kata kerja, dan kata sifat yang dekat dengan lingkungannya sehari-hari. Walaupun yang diucapkan suku kata terakhir saja, namun mempunyai makna yang sudah bisa dipahami oleh orang tuanya.
Berikut ini adalah jenis kata anak usia 1 tahun.

\begin{tabular}{|c|l|l|}
\hline \multirow{2}{*}{ No } & \multicolumn{2}{|c|}{ KATA BENDA } \\
\cline { 2 - 3 } & Kata & \multicolumn{1}{c|}{ Arti } \\
\hline 1 & yah & Ayah = Ayah \\
\hline 2 & Bu-b & Ibu = Ibu \\
\hline 3 & nnek & Nenek = Nenek \\
\hline 4 & kek & Kakek = kakek \\
\hline 5 & mih & mami = mami \\
\hline 6 & aek & Mak gaek = nenek \\
\hline 7 & tuk & datuk = Kakek \\
\hline 8 & cik & Aciak = Paman \\
\hline
\end{tabular}

\begin{tabular}{|c|l|l|}
\hline \multirow{2}{*}{ No } & \multicolumn{2}{|c|}{ KATA KERJA } \\
\cline { 2 - 3 } & Kata & \multicolumn{1}{c|}{ Arti } \\
\hline 1 & mam & mamam = Makan \\
\hline 2 & num & Minum = Minum \\
\hline 3 & dak & Indah = Tidak \\
\hline 4 & Pi-pin & Upin-ipin = nonton \\
\hline
\end{tabular}

\begin{tabular}{|c|l|c|}
\hline \multirow{2}{*}{ No } & \multicolumn{2}{|c|}{ KATA SIFAT } \\
\cline { 2 - 3 } & Kata & Arti \\
\hline 1 & cak & Rancak = bagus \\
\hline
\end{tabular}

Kata-kata yang didengan anak dari lingkungannya dapat diperoleh dengan baik. Misalnya ketika ditanya "sia tu na?" (itu siapa na?) anak langsung berkata ah (ayah), bu (ibu), cik (Aciak), mih (mami), ak (apak). Kemudian apabila ditanya "apo tu na?" (itu apa na?) sambil menunjukkan tangannya dan berkata pi-pin (pilem upinipin), aek (mak gaek).

\section{Tahap Pemerolehan Bahasa Pertama}

Seorang anak tidak secara tiba-tiba memiliki tata bahasa yang teratur dalam otaknya. Tahap pemerolehan bahasa pertama berkaitan dengan perkembangan bahasa anak. Hal ini dikarenakan bahasa pertama diperoleh seseorang pada saat ia berusia anak-anak. Menurut Ardiana dan 
Syamsul Sodiq (Ardiana dan Sodiq, 2000) terdapat empat tahap:

\section{Tahap Pemerolehan Kompetensi dan Performansi}

Kompetensi adalah pengetahuan tentang gramatika bahasa ibu yang dikuasai anak secara tidak sadar. Gramatika itu terdiri atas tiga komponen, yaitu semantik, sintaksis, dan fonologi dan diperoleh secara bertahap. Pada tataran kompetensi ini terjadi proses analisis untuk merumuskan pemecahan-pemecahan masalah semantik, sintaksis, dan fonologi. Sebagai pusat pengetahuan dan pengembangan kebahasaan dalam otak anak, kompetensi memerlukan bantuan performansi untuk mengatasi masalah kebahasaan anak. Performansi adalah kemampuan seorang anak untuk memahami atau mendekodekan dalam proses reseptif dan kemampuan untuk menuturkan atau mengkodekan dalam proses produktif. Sehingga dapat kita gambarkan bahwa kompetensi merupakan bahannya dan performansi merupakan alat yang menjembatani antara bahan dengan perwujudan fonologi bahasa.

\section{Tahap Pemerolehan Semantik}

Pemerolehan sintaksis bergantung pada pemerolehan semantik. Struktur pertama diperoleh oleh anak bukanlah struktur sintaksis melainkan makna (semantik). Sebelum mampu mengucapkan kata sama sekali, anak-anak rajin mengumpulkan informasi tentang lingkungannya. Anak menyusun fitur-fitur semantik (sederhana) terhadap kata yang dikenalnya. Hal yang dipahami dan dikumpulkan oleh anak itu akan menjadi pengetahuan tentang dunianya. Pemahaman makna merupakan dasar pengujaran tuturan.
Salah satu bentuk awal yang dikuasai anak adalah nomina, terutama yang akrab atau dekat dengan tempat tinggalnya. Dalam penelitian ini, subjek penelitian terlebih dahulu menguasai nomina yang berkaitan dengan anggota keluarga dan kerabat dekat. Subjek penelitian juga sudah mampu mengujarkan benda di sekelilingnya yang diketahui oleh subjek penelitian. Setelah menguasai nomina di sekitar anak, anak mulai menguasai verba secara bertingkat, dari verba yang umum menuju verba yang lebih khusus atau rumit. Verba yang berkaitan dengan kehidupan sehari-hari, seperti makan, mandi, minum, dan Pi-Pin (Upin-Ipin yang berarti tontonan atau ketika subjek penelitian ingin menonton). Subjek penelitian juga sudah mampu mengujarkan kata sifat yaitu kata "cak" yang berarti bagus. Anak sudah mengerti mengenai kata sifat dan mengerti makna kata bagus.

\section{Tahap Pemerolehan Sintaksis}

Konstruksi sintaksis pertama anak normal dapat diamati pada usia 18 bulan. Meskipun demikian, beberapa anak sudah mulai tampak pada usia setahun dan anakanak yang lain di atas dua tahun. Pemerolehan sintaksis merupakan kemampuan anak untuk mengungkapkan sesuatu dalam bentuk konstruksi atau susunan kalimat. Konstruksi itu dimulai dari rangkaian dua kata. Konstruksi dua kata tersebut merupakan susunan yang dibentuk oleh anak untuk mengungkapkan sesuatu. Anak mampu untuk memproduksi bahasa sasaran untuk mewakili apa yang ia maksud. Pemakaian dan pergantian katakata tertentu pada posisi yang sama menunjukkan bahwa anak telah menguasai kelas-kelas kata dan mampu secara kreatif memvariasikan fungsinya. Contohnya adalah 'ayah datang'. Kata tersebut dapat divariasikan anak menjadi 'ayah pergi' atau 'ibu datang'. 


\section{Tahap Pemerolehan Fonologi}

Secara fonologis, anak yang baru lahir memiliki perbedaan organ bahasa yang amat mencolok dibanding orang dewasa. Berat otaknya hanya $30 \%$ dari ukuran orang dewasa. Rongga mulut yang masih sempit itu hampir dipenuhi oleh lidah. Bertambahnya umur akan melebarkan rongga mulut. Pertumbuhan ini memberikan ruang gerak yang lebih besar bagi anak untuk menghasilkan bunyi-bunyi bahasa.

Pemerolehan fonologi atau bunyibunyi bahasa diawali dengan pemerolehan bunyi-bunyi dasar. Menurut Jakobson (Ardiana dan Sodiq, 2000) bunyi dasar dalam ujaran manusia adalah /p/, /a/, /i/, /u/, /t/, /c/, /m/, dan seterusnya. Kemudian pada usia satu tahun anak mulai mengisi bunyi-bunyi tersebut dengan bunyi lainnya. Misalnya /p/ dikombinasikan dengan /a/ menjadi pa/ dan /m/ dikombunisakan dengan /a/ menjadi /ma/. Setelah anak mampu memproduksi bunyi maka seiring dengan berjalannya waktu, aanak akan lebih mahir dalam memproduksi bunyi. Hal ini dipengaruhi oleh lingkungan, kognitif dan juga alat ucapnya.

Supaya lebih memperjelas tahaptahap pemerolehan bahasa pertama tersebut, maka di bawah ini diuraikan tahap-tahap pemerolehan bahasa seorang anak. Menurut Arifuddin (Arifuddin, 2010) tahap pemerolehan bahasa dibagi menjadi empat tahap, yaitu praujaran, meraban, tahap satu kata, dan tahap penggabungan kata sebagai berikut.

\section{Tahap Praujaran}

Pada tahap ini, bunyi-bunyi bahasa yang dihasilkan anak belumlah bermakna. Bunyi-bunyi itu memang telah menyerupai vokal atau konsonan tertentu. Tetapi, secara keseluruhan bunyi tersebut tidak mengacu pada kata dan makna tertentu.
Fase ini berlangsung sejak anak lahir sampai berumur 12 bulan.

a) Pada umur 0-2 bulan, anak hanya mengeluarkan bunyi-bunyi refleksif untuk menyatakan rasa lapar, sakit, atau ketidaknyamanan. Sekalipun bunyibunyi itu tidak bermakna secara bahasa, tetapi bunyi-bunyi itu merupakan bahan untuk tuturan selanjutnya.

b) Pada umur 2-5 bulan, anak mulai mengeluarkan bunyi-bunyi vokal yang bercampur dengan bunyi-bunyi mirip konsonan. Bunyi ini biasanya muncul sebagai respon terhadap senyum atau ucapan ibunya atau orang lain.

c) Pada umur 4-7 bulan, anak mulai mengeluarkan bunyi agak utuh dengan durasi yang lebih lama. Bunyi mirip konsonan atau mirip vokalnya lebih bervariasi.

d) Pada umur 6-12 bulan, anak mulai berceloteh. Celotehannya merupakan pengulangan konsonan dan v okal yang sama seperti/ba ba ba/, ma ma ma/, da da da/.

\section{Tahap Satu Kata}

Fase ini berlangsung ketika anak berusia 12-18 bulan. Pada masa ini, anak menggunakan satu kata yang memiliki arti yang mewakili keseluruhan idenya. Tegasnya, satu kata mewakili satu atau bahkan lebih frase atau kalimat. Oleh karena itu, frase ini disebut juga tahap holofrasis. Subjek penelitian berada pada tahap ujaran satu kata ini. Subjek penelitian mulai bisa mengujarkan bendabenda dan orang-orang yang berada di sekitar subjek penelitian.

\section{Tahap Dua Kata}

Fase ini berlangsung sewaktu anak berusia sekitar 18-24 bulan. Pada masa ini, kosakata dan gramatika anak berkembang dengan cepat. Anak-anak mulai menggunakan dua kata dalam berbicara. 
Tuturannya mulai bersifat telegrafik. Artinya, apa yang dituturkan anak hanyalah kata-kata yang penting saja, seperti kata benda, kata sifat, dan kata kerja. Kata-kata yang tidak penting, seperti halnya kalau kita menulis telegram, dihilangkan.

\section{Tahap Penggabungan Kata}

Fase ini berlangsung ketika anak berusia 3-5 tahun atau bahkan sampai mulai bersekolah. Pada usia 3-4 tahun, tuturan anak mulai lebih panjang dan tata bahasanya lebih teratur. Dia tidak lagi menggunakan hanya dua kata, tetapi tiga kata atau lebih. Pada umur 5-6 tahun, bahasa anak telah menyerupai bahasa orang dewasa.

\section{KESIMPULAN}

Berdasarkan hasil penelitian tersebut dapat disimpulkan bahwa pemerolehan bahasa adalah proses-proses yang berlaku di dalam otak anak ketika memperoleh bahasa ibunya. Pemerolehan bahasa pertama terjadi di kehidupan awal seorang anak. Pemerolehan bahasa pertama seorang anak sangat dipengaruhi oleh lingkungan keluarga di sekitar anak. Dalam hal nilainilai sosial budaya yang teranut pada bahasa akan terinternalisasi pada bawah sadar manusia. Kemudian, seiring berjalannya waktu dan pertumbuhan si anak, maka anak akan memperoleh bahasa selain bahasa yang diajarkan ibunya, baik bahasa kedua, ketiga ataupun seterusnya, tergantung dengan lingkungan sosial dan tingkat kognitif yang dimiliki oleh anak melalui proses pembelajaran. Bahasa pertama berkenaan dengan pemerolehan bahasa, sedangkan dengan bahasa kedua berkenaan dengan pembelajaran bahasa.

Dari hasil pengamatan dapat disimpulkan bahwa pemerolehan bahasa pertama anak usia satu tahun dari aspek perkembangan morfologi pada anak bernama Zayna Falisa Humaira sangat baik. Subjek penelitian sudah menguasai

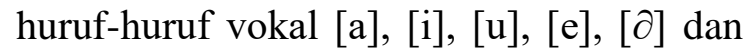
[o]. Pada usia satu tahun anak ini telah memiliki perkembangan bahasa yang sangat baik, ia mampu menguasai katakata yang berada disekitarnya. Subjek penelitian juga sudah mampu mengujarkan beberapa kata benda, kata kerja, dan kata sifat.

\section{UCAPAN TERIMA KASIH}

Penulis menyampaikan ucapan terima kasih kepada orang tua subjek yang telah memberi persetujuan dan membantu peneliti selama proses pengumpulan data. Penulis juga mengucapkan terima kasih kepada pembimbing yang sudah membantu peneliti dalam menyempurnakan hasil penelitian ini. Ucapan terima kasih juga disampaikan kepada tim editor Jurnal Obsesi yang telah memberikan saran, kritik, dan rekomendasi untuk perbaikan artikel ini.

\section{DAFTAR PUSTAKA.}

Amelin. (2019). Understanding the language of children 12-14 months based on non-linguistic elements. Obsesi, 3(1).

Ardiana dan Sodiq. (2000). Psikolinguistik. Jakarta: Universitas Terbuka.

Arifuddin. (2010). Neuropsikolinguistik. Jakarta: Raja Grafindo Persada.

Chaer. (2003). Psikolinguistik: Kajian Teoritik. Jakarta: Rineka Cipta.

Dardjowidjojo. (2003). Psikolinguistik. Pengantar Pemahaman Bahasa Manusia. Jakarta: Yayasan Obor Indonesia.

Kridalaksana. (2002). Struktur, kategori, dan fungsi dalam teori sintaksis. Universitas Katolik Indonesia Atma Jaya. 
Miles dan Huberman. (2014). Analisis data kualitatif: buku sumber tentang metode-metode baru (terjemahan Tjetjep Rohendi Rohidi). Jakarta: UI Press.

Nazir. (2011). Metode penelitian. Jakarta: Ghalia Indonesia.

Palenkahu. (2005). Pemerolehan Bahasa Pertama Anak Kembar Usia Dua Tahun Delapan Bulan (Makalah. U).

Salnita. (2019). Language Acquisition for Early Childhood. Obsesi, 3(1).

Solehan. (2011). Pendidikan bahasa Indonesia. Jakarta: Universitas Terbuka.

Tarigan. (1988). Pengajaran Pemerolehan Bahasa. Bandung: Angkasa.

Troike. (2006). Introducing Second Language. Cambridge: Cambridge University Press.

Yogatama, A. (2011). Pemerolehan bahasa pada anak usia 3 tahun ditinjau dari sudut pandang morfosintaksis. LENSA, 1(1).

Yumi. (2019). Children's peformance sentence in simple construction time. Obsesi, 3(1). 